\title{
„Miałem dziś przedziwny sen...". Arte e amore w onirycznych zapiskach Dziennika 1957-1958 Gustawa Herlinga-Grudzińskiego
}

\section{Abstract \\ „I had the strangest dream...". Arte e amore in dreamlike notes of Gustaw Herling-Grudziński’s Dziennik 1957-1958}

The purpose of this article is to discuss dreamlike themes of Gustaw Herling-Grudziński's Diary 1957-1958. The dream descriptions reveal the part of the writer's spiritual biography that comes to the fore from the subconscious. Sleep plays an important role in showing the deepest emotions and mental states of the speaking subject. The dream records reveal more than the author tells about himself directly. They help to interpret the subject's hidden emotions, his state of mind, reveal repressed psychological contents, a result of painful personal experiences. They relate to the most important topics for the writer, such as artistic creativity (inspiration and the process of creating a work) and love to Krystyna, his first wife.

Key words: Gustaw Herling-Grudziński, diary, dream in literature

Słowa kluczowe: Gustaw Herling-Grudziński, dziennik, sen w literaturze 
Dopóki nie pozna się bliżej tajemnicy snów, nie będzie się miało wiele do powiedzenia o tajemnicy życia i śmierci.

(G. Herling-Grudziński 2018: 229)

Osobisty dziennik Gustawa Herlinga-Grudzińskiego z lat 1957-1958 (Grudziński 2018') odnalazła w archiwum ojca i przygotowała do druku, we współpracy z Włodzimierzem Boleckim, Marta Herling. Diariusz obejmuje niemal piętnaście miesięcy z życia pisarza, wówczas mieszkającego już od prawie roku w Neapolu, do którego przeprowadził się z Monachium po zakończeniu pracy w Radio Wolna Europa. Miał wówczas 38 lat i był w związku małżeńskim z Lidią Croce. Tęsknota żony za miastem pochodzenia oraz chęć oderwania się pisarza od tragicznych osobistych wspomnień kilka lat po samobójczej śmierci pierwszej żony Krystyny Stojanowskiej (której zresztą poświęca w Dzienniku wiele miejsca) zdecydowały o przeprowadzce do włoskiego miasta położonego u stóp Wezuwiusza, choć początkowo pisarz nie czuł się tu dobrze. W Neapolu doskwierała mu samotność, przede wszystkim był odizolowany od wszystkiego, co polskie, nad czym bardzo ubolewał. W zapiskach z 2 stycznia 1958 roku dzieli się uczuciem przygnębienia z powodu braku listów z Polski, stawiając retoryczne pytanie: „Czyżby do tego stopnia człowiek był zależny od swego narodowego otoczenia (spojrzeń włoskich mam aż za dużo)?” (s. 227). Dwa tygodnie później, 16 stycznia, pisze, że wiele by dał, by móc z kimś pić i mówić nie po włosku (s. 241). W jednym z wywiadów w odpowiedzi na pytanie, co było w tym mieście najtrudniejsze, odpowiada:

- Izolacja. To jest miasto zamknięte w sobie, nie interesuje się inną tematyką niż neapolitańska. [...] W pierwszych latach ta „nieprzenikalność” Neapolu była dla mnie bardzo uciążliwa. Lidia ciągnęła mnie na rozmaite przyjęcia włoskie, gdzie ja siedziałem milczący i ponury. Sprawy, które mnie interesowały, były absolutnie obce Włochom (Sawicka 1997: 53).

Poczucie izolacji potęgował fakt, że w życiu intelektualnym kraju dominowała obca pisarzowi światopoglądowo włoska partia komunistyczna, której członkowie traktowali z rezerwą emigrantów o poglądach krytycznych wobec Kremla. Herling-Grudziński wspomina, iż w jednym z komunistycznych pism („Paese Sera”) ukazał się artykuł, którego autor domagał się wydalenia go z Włoch (Herling-Grudziński 2000: 58). Córka zwraca uwagę na fakt, iż jako antykomunista był źle widziany, a jego książki były zakazane w niektórych środowiskach, co więcej, nie wolno było kontaktować się z nim studentom polonistyki uniwersytetu w Neapolu.

Dziennik jest przede wszystkim zbiorem bieżących zapisków wydarzeń z kolejnych dni. Znalazły się w nim informacje o życiu osobistym pisarza, jego rodzinie,

$1 \mathrm{~W}$ dalszej części artykułu cytaty z tego wydania lokalizuję, podając stronę.

34

Fabrica Litterarum Polono-Italica | 2021, nr 1 (3) 
dzieciach, ich zdrowiu, problemach małżeńskich, refleksje ze spotkań z Polakami z kraju i emigracji. W opisach tych Herling posługuje się językiem oszczędnym, niemal sprawozdawczym, koncentruje się na relacjonowaniu faktów, ograniczając ocenę czy osobisty komentarz do celnej pointy.

Omawiany Dziennik doczekał się kilku recenzji. Piotr Kieżuń podkreśla osobisty charakter notatek, które stanowią „rodzaj autoterapii” po bolesnych doświadczeniach. Pisarz powoli wydobywa się z depresji i próbuje zaadaptować do nowych warunków (Kieżuń 2018). Dla Konrada Zycha dziennik ten jest wstępem do „właściwej pracy pisarskiej”, miejscem „krystalizowania się poglądów estetycznych autora”. To „zapis jego rosnącej samoświadomości, ale i żmudnej okołoliterackiej »roboty« (Zych 2018: 203). Marcin Cielecki zwraca uwagę na wyraźną różnicę w stylistyce między innymi dziennikami Herlinga a Dziennikiem 1957-1958 - nieprzeznaczonym do publikacji. To „diariusz w stanie surowym, z wszelkimi chropowatościami faktury" (Cielecki 2018). Grzegorz Bogdał, osadzając dziennik na tle biografii pisarza i konfrontując go z opowiadaniami, stawia pytanie o sens publikowania tego typu tekstu, skoro autor sam nie zdecydował się na jego wydanie (Bogdał 2018: 68). Wszyscy recenzenci zwracali uwagę na intymność zapisków Herlinga. Być może właśnie ten kontrowersyjny aspekt notatek okazał się dla wydawców najbardziej frapujący i ciekawy. Jak pisze we wstępie Włodzimierz Bolecki, „o znaczeniu tego utworu w dorobku pisarza decyduje niezwykła, wyjątkowo osobista, głęboko prywatna perspektywa narracyjna”, „głęboka prywatność i niemaskowana niczym szczerość” powodują, że zapiski te „można traktować jako wewnętrzną rozmowę pisarza z samym sobą, jako specyficzne soliloquium” (zob. Bolecki 2018: 9-10). Ten rys stylistyczny i tematyczny dziennika odróżnia go znacznie od zapisków w powstałych później tomach Dziennika pisanego noca, gdzie zaczyna dominować tok eseistyczny, do którego wplecione są elementy fikcji literackiej. Prowadzi to do zerwania paktu autobiograficznego (Adamczyk 1994: 112-113), który w omawianym tu dzienniku jest jeszcze bardzo silnie obecny². Nie mamy wątpliwości, że narrator to autor dzielący się z czytelnikiem osobistymi refleksjami.

Celem niniejszego szkicu jest zwrócenie uwagi na oniryczny aspekt Dziennika. Wydaje się on ciekawy ze względu na fakt, że opisy snów ujawniają tę część duchowej biografii pisarza, która dochodzi do głosu z podświadomości. Odgrywają one ważną rolę w ukazaniu najgłębszych przeżyć i stanów psychicznych podmiotu mówiącego. Ich zapisy ujawniają więcej, niż autor relacjonuje o sobie bezpośrednio, gdyż otwierają się na interpretację. Jak pisze Aleksandra Okopień-Sławińska, badając miejsce snów w dziele literackim:

2 Odstępstwem od tego są kończące dziennik zapiski z podróży na południe Włoch w maju 1958 roku, zatytułowane Słońce i śmierć, które - jak pisze Marta Herling - „uzyskują spójność narracyjną i stylistyczną właściwą opowiadaniu" (Herling 2018: 345).

35

Fabrica Litterarum Polono-Italica | 2021, nr 1 (3) 
Sny odsłaniają tajemnicę - przyszłości, teraźniejszości lub przeszłości: mogą być przesłaniem skierowanym ku człowiekowi przez moce nadprzyrodzone, wejrzeniem w zaświaty i zagadkę istnienia, stanem zjednoczenia duszy z wszechbytem, ujawnieniem stłumionych i nieuświadamianych treści psychicznych, wyrosłych z indywidualnych urazów lub doświadczenia gatunkowego (Okopień-Sławińska 1973: 8).

W dzienniku Grudzińskiego sny dotykają wszystkich powyższych aspektów, przy czym najistotniejsze tematy, których są wyrazem, to t wó r c zość a r tyst y c z na (natchnienie i proces powstawania dzieła) oraz miłość - w tym wypadku do pierwszej żony Krystyny.

\section{„...śni mi się co nocy pisanie” Włoskie lektury, Scirocco i twórcze natchnienie}

Gdyby można było pisać we śnie!

(G. Herling-Grudziński 2018: 45)

Jednym z najistotniejszych tematów dziennika jest pisanie. Herling często ubolewa z powodu kryzysu twórczego. Z wielkim trudem powstaje powieść Ciemny staw, którą autor ostatecznie zniszczy. Niewiele brakowało, a zniszczyłby powstające wówczas opowiadanie Wieża. Pisarz był wobec siebie bardzo wymagający. Z trudem znosił dłuższe okresy twórczej niemocy. Choć - jak wynika z notatek dziennika - Herling prowadził życie towarzyskie, korzystał z dobrodziejstw miasta (był bywalcem kawiarń, chodził do teatru i na koncerty, zwiedzał zabytki, współpracował i spotykał się z redaktorami „Tempo Presente”), pisał dla londyńskich „Wiadomości”, współpracował z paryską „Kulturą”, nie czuł się spełniony. Niekiedy, wyciągany przez żonę do teatru czy na koncerty włoskiej muzyki, traktował te wypady jak niepotrzebne odrywanie od pisania:

Wieczorem pojechaliśmy na Trinità Maggiore posłuchać płyt z nagraniami operowymi Toscaniniego. Byłem zmęczony i zły na Lidię, że mnie oderwała od biurka, i dlatego słuchałem z oporami. Zdaje się, że ładny jest Falstaff i Otello, okropna Traviata. Ale to tylko Verdi. (s. 66-67)

Podobnie traktował nierzadko wizyty włoskich znajomych i członków rodziny Croce („Kiedy się wreszcie skończą te wszystkie wizyty?”; s. 69-71), podkreślając, że utrudniają mu skupienie się na pracy.

36

Fabrica Litterarum Polono-Italica | 2021, nr 1 (3) 
Z diariusza możemy wyczytać, że czasem to, co mogłoby ujawnić się w procesie twórczym, zyskuje formę w sennych marzeniach, które mogą być inspiracją dla wyobraźni artysty. Niestety, jest to materia krucha, której często nie sposób po przebudzeniu zatrzymać:

Miałem dziś przedziwy sen, o którym mogę powiedzieć tylko jedno: że w czasie gdy się śnił, był zdumiewająco jasny, logiczny, miał swoją fabułę i dramatyczność, a wkrótce po przebudzeniu się pękł tak szybko, że nie udało mi się nawet pozlepiać z odłamków jego fragmentów. (s. 33)

Podobnie w zapiskach z 18 stycznia 1957 roku nieuchwytny, ulotny sen jawi się jako swoisty doskonały wzorzec narracyjny:

Sen przedziwny - szczegółów nie pamiętam. Jedno wydaje się pewne: sen ma czystość i logikę sztuki i nic w nim nie dziwi, na jawie mamy ociężałą wyobraźnię. (s. 45)

Trzy miesiące później zaznaczy to w zapiskach jeszcze wyraźniej. Wspomina powtarzający się od kilku dni sen, w którym tworzy z przekonaniem, że powstające dzieło jest bardzo dobre. Ma przy tym świadomość śnienia, więc stara się wszystko zapamiętać, by na jawie przelać na papier. Jednak po przebudzeniu „wszystko rozpływa się jak... Oczywiście jak sen" (s. 123). Niekiedy fabuła marzeń sennych, konstrukcja snu przypomina tę znaną z ważnych lektur na jawie. Przykładem jest sen z 28 marca 1958 roku, przypominający w swej wymowie dzieła Kafki:

Dworzec (sen):

Codziennie w nocy przyprowadzają na dworzec tych, którzy mają umrzeć. Dookoła nisze z pluszowymi stołkami, na których ci, co mają umrzeć, kładą głowy, i klęcznikami. Niektórych odprowadzają rodziny, inni przychodzą sami. Rodzinom wolno przebywać z mającymi umrzeć do ostatniej chwili, a nawet z ich zwłokami. Samotni spędzają ostatnie chwile, czyszcząc sobie karki przed ścięciem. Przewodnik zapytany, czy nie umierają nigdy oprawcy, odpowiada: Nie. Ci są potrzebni.

Kafkowski sen! (s. 265)

Choć przywołany sen nie miał bezpośredniego związku z lekturami (Herling pisze: „Nie czytałem od wielu miesięcy Kafki”; s. 265), jest wyrazem podświadomie zakorzenionych myśli o śmierci, której przejawy otaczają autora od lat - począwszy od licznych poległych na wojnie i w sowieckim obozie, aż po samobójcze śmierci bliskich osób, o których wspomnienie jest jeszcze stosunkowo świeże (żona Krystyna, Andrzej Ciołkosz - syn przyjaciół). Dworzec kolejowy w marzeniach sennych 
oznacza, podobnie jak sen o śmierci, czas nadchodzących nieodwracalnych zmian, rozstań, nowego otwarcia. Dominuje w nim również uczucie niemocy, bezradności wobec śmierci, o której decyduje wyższa instancja. Z dużym prawdopodobieństwem można założyć, że opisywane w dzienniku sny nie są kreacją literacką, lecz autentycznym przeżyciem opisującego, choć w późniejszej twórczości zarówno śmierć, jak i sen będą stanowiły ważne motywy w opowiadaniach Herlinga. W rozmowie z Boleckim zaznacza, że samobójstwo to jeden z jego obsesyjnych tematów (Herling-Grudziński, Bolecki 2009: 35). Pojawia się on zresztą już w zamykającej dziennik części narracyjnej, będącej relacją z Kalabrii, gdy mowa o romantycznych samobójstwach w Paestrum, literatura przenika życie. Nie tylko w ten sposób, że tematy z rzeczywistości stają się materią literacką, ale i dlatego, że stan psychiczny autora może blokować powstawanie dobrego dzieła:

Zaczyna się kryzys: nagle po tych paru dobrych miesiącach cofnięcie się do okresu, kiedy nie mogłem nic robić i nie chciało mi się nic robić. Czym to jest spowodowane? Stanem fizycznym czy wyjściem na wierzch jakichś spychanych i niezałatwionych spraw psychicznych? (s. 209)

Czy na podstawie Dziennika można określić ówczesne gusta literackie autora? Co go ciekawi, a może fascynuje w literaturze włoskiej? Punktem wyjścia w odpowiedzi na to pytanie jest określenie, co Herlinga interesowało w każ dej literaturze, niezależnie od kraju pochodzenia. Takim tematem był człowiek, jego kondycja w świecie, sposoby odnajdywania się wobec dylematów doczesności. Taką tematykę sam podejmował w swoich utworach. Wspominając lekturę Tristana i Izoldy, pisze, że „należy opowiadać tylko to, co najważniejsze” (s. 231). W ocenach nie kierował się sławą czy popularnością autora, ale własnym zdaniem. Dzięki lekturze Dziennika dowiadujemy się, że znacznie wyżej od włoskiej ceni prozę angielską. Ta pierwsza „przelewa się przez palce”, podczas gdy druga jest znacznie wnikliwsza „w odczytywaniu charakterów i plastyce rozmów” (s. 95). Refleksje na temat literatury pojawiają się w tekście jako podsumowania sytuacji towarzyskich. Przywołana tu, sytuująca wyżej literaturę angielską nad włoską, znalazła się jako podsumowanie relacji ze spotkania ze szwagierką Sylvią, snującą opowieść o swych miłosnych perypetiach, przeplatając angielszczyznę włoskimi wtrąceniami. W innym miejscu dziennika znajdujemy ocenę dramatu Pirandella Questa sera si recita a soggetto, sformułowaną po wizycie w teatrze na spektaklu, potwierdzającą wcześniejszą opinię o włoskiej literaturze: w utworze Pirandella „truizm rozdmuchany jest do rozmiarów wielkiej prawdy filozoficznej, nie będąc nią" (s. 119). Nie są to jedyne zapiski, podsumowujące lekturę włoskiego dramaturga. W notatce z 3 czerwca 1957 roku, po dłużącym się dniu twórczej niemocy wspomina kojącą lekturę nowel

38

Fabrica Litterarum Polono-Italica | 2021, nr 1 (3) 
Pirandella i Dąbrowskiej. Może „kojącą” w tym sensie, że u obojga autorów nie znalazł oczekiwanej głębi:

Mucha Pirandella dobra, Czarny szal - „młodopolski”. Trzeba zazdrościć pisarzom, którzy jak Dąbrowska potrafią tak swobodnie, nie bez pewnego wdzięku i ze swadą mówić, nie mając wiele do powiedzenia. (s. 211)

Owa konstatacja pokazuje istotną cechę Herlinga: nie kieruje się on w ocenie pochodzeniem autora, ale wartością literacką i filozoficzną dzieła. Nieco bardziej łaskawy był Herling wobec komedii Eduarda De Filippa Natale in casa Cupiello („Zabawne z wyjątkiem trzeciego aktu” (s. 209)). Powyższe komentarze do lektur są zresztą charakterystyczne dla sposobu zapisywania przez Herlinga większości wydarzeń w dzienniku - są to zapisy zwięzłe, sprawozdawcze, raczej lakoniczne, czasem dosadne. Nie znaczy to, że nie ma wyjątków. Znacznie dłuższe i głębsze rozważania na temat Pirandella znajdziemy w zapiskach z 15 lutego 1957 roku w rozważaniach inspirowanych wizytą w teatrze na spektaklu Cosi è se vi pare. W zestawieniu z egzystencjalizmem Sartre’a wcześniejsza myśl włoskiego pisarza wydaje się trafną diagnozą kondycji człowieka:

Różnica jest ta, że o ile Sartre twierdził, że „nie skorupa stanowi o naczyniu, lecz jego wewnętrzna pustka", to Pirandello był ostrożniejszy - dla niego jest coś w naczyniu, lecz to coś jest nieznane ani naczyniu, ani patrzącym na nie. Nie ma prawdy i nie ma rzeczywistości, jest tyle prawd i rzeczywistości, ilu ludzi. Nawet człowiek nie wie nic o sobie i wystarczy, że staje przed lustrem, by zaczął mieć wątpliwości. Dwóch, a nawet odbicie jednego tworzy wątpliwość i względność. (s. 87)

Dziennik jest także świadectwem otwartości autora na nowe włoskie lektury i doświadczenia związane z percepcją sztuki. Wspomnieniom konkretnych spotkań ze znajomymi towarzyszą zapiski o inspirujących do dalszych poszukiwań artystycznych przeżyciach (słuchanie muzyki Domenico Cimarosy czy lektura Machiavellego; s. 97). Percepcja muzyki i książkowe lektury stają się lekarstwem w okresach literackiej bezpłodności. Inspiracją stają się również włoskie pejzaże, miejsca o ciekawej i tajemniczej historii. W ostatniej części dziennika, ujawniającej żywioł narracyjny, zwraca uwagę malowniczość opisów, wrażliwość na kolory. Zdolność do aktywności twórczej warunkowana jest niekiedy włoską aurą:

Po obiedzie, na spacerze, poczułem sirocco i wróciłem do domu jak dziurawa piłka - gdzie nacisnąć, to się wgniata i nie wraca do dawnej pozycji. Próbowałem pisać, nie szło mi to, a nawet zbrzydziło to wszystko, co dotąd napisałem. Stąd wniosek, że nie trzeba nigdy pisać na siłę. (s. 76-77) 
Podobnie w notatce z 9 lutego, w której pisze: „Sirocco, nie robiłem nic [...]” (s. 79). Zależność tę celnie podsumowuje Magdalena Bauchrowicz-Kłodzińska:

Zdumiewające jest [...], że skrupulatne opisy psychofizycznych kryzysów czy niedyspozycji diarysty często łączą się z jego uwagami na temat specyficznej aury Południa. W codziennym doświadczeniu autora Dziennika tak charakterystyczne dla tego regionu scirocco - suchy i gorący wiatr, w którym niemalże czuć duszący oddech czy spopielający wszystko pocałunek afrykańskich pustyń, urasta do rangi oryginalnej metafory jako fizykalnie konkretny ekwiwalent egzystencjalnego niepokoju pisarza, a zwłaszcza boleśnie odczuwanej przezeń twórczej niemocy (2018: 21).

\section{„Śniła mi się Krystyna” - diarystyczne zapisy tęsknoty}

mimo tych paru metrów odległości

staliśmy w dwóch straszliwie dalekich światach

(Herling-Grudziński 2018: 267)

Bardzo istotną część zapisków diarystycznych stanowią opisy snów, związanych ze zmarłą samobójczą śmiercią pierwszą żoną pisarza. To bolesne doświadczenie wywarło ogromny wpływ na jego dalsze życie. W dzienniku zdarzają się aluzje do myśli samobójczych. Choć małżeństwo nie trwało długo, odegrało istotną rolę w życiu Herlinga jako mężczyzny, ale i twórcy, który w innym miejscu wspomina:

Moja pierwsza żona Krystyna była malarką, bardzo się kochaliśmy; ja oglądałem to, co ona namalowała, a ona czytała to, co ja napisałem - a to w życiu pisarza jest niesłychanie ważne. Krystyna była moją pierwszą czytelniczką, tak jak ja byłem pierwszym widzem, który oglądał jej obrazy (Herling-Grudziński 2000: 75).

Uczucie do zmarłej żony nie wygasa jeszcze przez wiele lat po jej śmierci. Szczególną rolę we wspomnieniach o niej odgrywa Rzym, gdzie małżonkowie mieszkali po ślubie. Herling wspomina: „Rzym stał się wtedy moją wielką miłością. Słusznie ktoś kiedyś napisał, że miejsca są dla nas wyrazem naszych uczuć. Dla mnie Rzym jest miastem, w którym byłem szczęśliwy z Krystyną i tego nigdy nie zapomnę" (Herling-Grudziński 2000: 52). Stąd w dzienniku relacje z tego miasta nacechowane są pozytywnie („Rzym podnieca mnie w niesamowity sposób”; s. 139). Kobiety spotkane w Rzymie, towarzyszki jego znajomych, czasem przypominają mu 
Krystynę. O małej Francuzce, towarzyszce Giordano pisze: „Podobieństwo między nią a Krystyną jest coraz bardziej uderzające" (s. 139). W innym miejscu, wspominając poranną kawę z Lią Wainstein i Vittorią Olivetti, skonstatuje: „Zdumiewające podobieństwo (w wielu szczegółach) tej drugiej do..." (s. 121). W jednym ze snów widzi Krystynę z twarzą własnej siostry Łucji („Śniła mi się Krystyna. Nie widziałem jej twarzy, ale wiem, że to była ona; raz miała twarz Luchny"; s. 227). Zatem zmarła żona miała twarz ukochanej siostry, z którą Herling był silnie związany i która odwiedzała go w Neapolu. Zapisywanie snów może mieć więc charakter terapeutyczny, wydobywa na powierzchnię świadomości ból i ukryte lęki. Snom o Krystynie towarzyszy niepokój, poczucie, że jest inaczej, niż by się chciało. Sen z 17 stycznia 1958 roku przynosi lęk przed rozstaniem:

Sen: szalenie jasna i blada Krystyna z długimi i rozpuszczonymi włosami, jakie nosiła w Warszawie, kiedy jej nie znałem. Mówiła o rozwodzie. Na pytanie dlaczego, odpowiedziała, że lepiej nie wymieniać powodów. Na moje błagania zawahała się, powiedziała, że się jeszcze namyśli. (s. 241)

Dziesięć dni później pojawia się opis kolejnego, pełnego niepokoju snu opisującego sytuację konfliktu z Krystyną. Typowe dla konwencji onirycznej jest w nim przemieszczanie się bohaterów w przestrzeni i czasie wbrew prawom natury. Mieszkanie, w którym spotykają się kochankowie, jest jednocześnie ich wspólnym mieszkaniem londyńskim, jak i kieleckim mieszkaniem z dzieciństwa pisarza: „Wyszedłszy z naszego pokoju w Londynie, znalazłem się w korytarzu prowadzącym do łazienki i kuchni mieszkania w Kielcach" (s. 253). W psychoanalitycznym odczytaniu marzeń sennych droga korytarzem może oznaczać stan zejścia do podświadomości, mierzenie się z wypartymi wewnętrznymi lękami i uczuciami. W tym wypadku to także symboliczny powrót do dzieciństwa, czasu pierwszych najsilniejszych doświadczeń, kształtujących odbiór świata w wieku dojrzałym. Herling bardzo boleśnie odczuł stratę żony i czas powstawania dziennika był okresem ciągle przeżywanej, choć - ze względu na nową sytuację rodzinną - ukrywanej żałoby, która w pewnym sensie mogła znaleźć ujście jedynie w snach. Co ciekawe, choć Krystyna pojawia się w marzeniach sennych jako osoba żywa, niemal w każdym przypadku spotkanie z nią wiąże się z groźbą jej utraty. We śnie z 3 marca 1958 roku o kompozycji szkatułkowej pojawia się problem trójkąta, senna rozmowa kochanków odsłania możliwość odejścia Krystyny z tym trzecim. Herling nie dokonuje w dzienniku szczegółowej analizy snów, raczej tylko je relacjonuje, czasem odtwarza własne uczucia, które zapamiętał z czasu śnienia. Bardzo charakterystyczny jest pod tym względem symboliczny sen z 2 kwietnia o przepaści, mimo przestrzennej bliskości, między nim a zmarłą żoną:

41

Fabrica Litterarum Polono-Italica | 2021, nr 1 (3) 
Sen: krzyczałem do stojącej o parę metrów ode mnie Krystyny: nie odwróciła się, nie spojrzała nawet na mnie. I we śnie wiedziałem, że nie dlatego, że ona była głucha lub ja niemy, ale dlatego, że mimo tych paru metrów odległości staliśmy w dwóch straszliwie dalekich światach. Nigdy jeszcze we śnie nie miałem tak wyraźnego odczucia dwóch rzeczy: ogromnej bliskości i nieskończonego oddalenia życia i śmierci oraz męki niesłyszanego krzyku. (s. 267)

W tej relacji, podobnie jak we wcześniejszych opisach wizji sennych, silnie zaznacza się poczucie rozłąki: już wyczuwanego bądź mającego nadejść rozdzielenia (niezależnie od tego, czy rozstanie to wiązałoby się ze śmiercią kobiety, czy z jej odejściem z kimś innym). Podobnie wygląda sen z 20 kwietnia: spotkanie kochanków naznaczone jest zapowiedzią odejścia kobiety, przeciwko któremu silnie protestuje mężczyzna. Ze snu tego Herling zachowuje pamięć o silnie odczuwanych emocjach: o chęci zatrzymania odchodzącej, choć ona sama nosi znamiona upływającego czasu (starzeje się), co potęguje poczucie oddalenia (s. 160-161). W opisach snów Herlinga czasem pojawia się refleksja osobistej natury: początkowo skupiona na relacji między dwojgiem ludzi, przeradza się w refleksję ogólniejszą: pojawia się pytanie: czym jest śmierć i co jest po niej („Może śmierć jest wiecznym snem, w którym po prostu żyje się inaczej?”; s. 161).

Dziennik mógłby stanowić ważne źródło dla badacza, który chciałby wykonać kalendarium życia i twórczości Herlinga-Grudzińskiego. To jednak, co wydaje się w nim najciekawsze, to próba rekonstrukcji stanu ducha pisarza, którego tragiczne doświadczenia osobiste silnie naznaczyły jego twórczą pracę; pisarza psychicznie osamotnionego, pozbawionego kontaktu z krajem, poranionego tragiczną śmiercią pierwszej żony człowieka, który bezskutecznie, nie zawsze świadomie usiłuje znaleźć ratunek przed wewnętrzną rozpaczą w pracy twórczej. Świadectwem takiej terapii przez pisanie może być powstający równolegle z dziennikiem dyptyk Skrzydła ołtarza. O opowiadaniu Wieża w rozmowie z Włodzimierzem Boleckim Herling powie, iż nie ma takiej fikcji literackiej, która nie miałaby „głębokiego impulsu w doświadczeniu autora" (Herling-Grudziński, Bolecki 1997: 154). Opowiadanie to zamyka cytat z utworu Borysa Pasternaka, który, odnosząc się do snu, dobrze oddaje grę między prawdą a fikcją w relacjach diarystycznych: „Niekiedy podczas snu to, co w nim oglądamy i przeżywamy, uderza nas jako coś nieistniejącego i równocześnie bardziej niż realnego". 


\section{Bibliografia}

Adamczyk Kazimierz (1994): Dziennik jako wyzwanie. Lechoń. Gombrowicz. Herling-Grudziński. Kraków.

Bauchrowicz-Kłodzińska Magdalena (2018): Rozczarowany i znużony. „Nowe Książki”, nr 3.

Bieńkowska Ewa (2002): Pisarz i los: o twórczości Gustawa Herlinga-Grudzińskiego. Warszawa.

Bogdał Grzegorz (2018): Monolog niewypowiedziany. „Tygodnik Powszechny”, nr 26.

Bolecki Włodzimierz (2005): Pamięć i sen. W: Idem: Ciemna miłość. Szkice do portretu Gustawa Herlinga-Grudzińskiego. Kraków.

Bolecki Włodzimierz (2018): "Co ze mnq będzie”. Dziennik sekretny Gustawa Herlinga-Grudzińskiego. W: G. Herling-Grudziński: Dziennik 1957-1958. Oprac. W. Bolecki, M. Herling. Kraków.

Cielecki Marcin (2020): Nocne kroki ojca. Online: https://instytutksiazki.pl/aktualnosci, 2,ksiazka-tygodnia-dziennik-1957-1958-gustawa-herlinga-grudzinskiego,1232.html [dostęp: 24.09.2020].

Freud Zygmunt (2007): Objaśnianie marzeń sennych. Przeł. R. Reszke. Warszawa.

Herling Marta (2018): Dziennik pisany dla samego siebie. W: G. Herling-Grudziński: Dziennik 1957-1958. Oprac. W. Bolecki, M. Herling. Kraków.

Herling-Grudziński Gustaw (2000): Najkrótszy przewodnik po sobie samym. Oprac. W. Bolecki. Kraków.

Herling-Grudziński Gustaw (2018): Dziennik 1957-1958. Oprac. W. Bolecki, M. Herling. Kraków.

Herling-Grudziński Gustaw, Bolecki Włodzimierz (1997): Rozmowy w Dragonei. Warszawa. Herling-Grudziński Gustaw, Bolecki Włodzimierz (2009): Rozmowy w Neapolu. Warszawa. Jacobi Jolande (1996): Psychologia C.G. Junga. Przedm. C.G. Jung. Przeł. S. Łypacewicz. Warszawa.

Kieżuń Piotr (2018): Zamknięty w sobie, zamknięty w pisarstwie. Recenzja „Dziennika 1957-1958” Gustawa Herlinga-Grudzińskiego. „Kultura Liberalna”, nr 25.

Okopień-Sławińska Aleksandra (1973): Sny i poetyka. „Teksty: teoria literatury, krytyka, interpretacja", nr 2 (8).

Owczarski Wojciech (2014): Sennik polski. Literatura, wyobraźnia i pamięć. Gdańsk.

Sawicka Elżbieta (1997): Widok z wieży. Rozmowy z Gustawem Herlingiem-Grudzińskim. Warszawa.

Zych Konrad (2018): G. Herling-Grudziński: „Dziennik 1957-1958”. [Rec.]. „Kwartalnik Artystyczny", nr 3.

43

Fabrica Litterarum Polono-Italica | 2021, nr 1 (3) 


\section{Abstract \\ „Ho fatto un sogno bizzarro oggi...”. Arte e amore nelle note oniriche del Dziennik 1957-1958 di Gustaw Herling-Grudziński}

Lo scopo di questo articolo è discutere dei temi onirici presenti nel diario Dziennik 1957-1958 di Gustaw Herling-Grudziński. Le descrizioni dei sogni rivelano quella parte della biografia spirituale dello scrittore che viene alla luce dal subconscio. Il sonno gioca un ruolo importante nel mostrare le emozioni e gli stati mentali più profondi del soggetto parlante. I racconti dei sogni svelano più di quanto riveli l'autore parlando di se stesso in modo diretto. I sogni aiutano a interpretare le emozioni nascoste del soggetto, il suo stato d'animo, rivelano contenuti psicologici repressi a seguito di dolorose esperienze personali riguardanti gli argomenti più importanti per lo scrittore, come la creatività artistica (l'ispirazione e il processo di creazione di un'opera) e l'amore per la prima moglie, Krystyna.

Parole chiave: Gustaw Herling-Grudziński, diario, sogno in letteratura 